\title{
MOTIVASI BERPRESTASI DAN GAYA KEPEMIMPINAN DALAM MENINGKATKAN MUTU PENDIDIKAN TAMAN KANAK-KANAK
}

\author{
Oleh: \\ Achmad Mauluddin \\ Balai Pengembangan Pendidikan Anak Usia Dan Pendidikan Masyarakat Kalimantan Selatan \\ (E-mail: achmad.mauluddin@,kemdikbud.go.id)
}

\begin{abstract}
ABSTRAK
Peran kepala sekolah sangat vital dalam mengembangkan dan meningkatkan mutu pendidikan yang sesuai dengan standar. Kepemimpinan kepala sekolah menjadi salah satu faktor penentu dalam proses pendidikan di sekolah yang dapat meningkatkan mutu pendidikan. Motivasi berprestasi dan gaya kepemimpinan kepala sekolah merupakan variabel yang mempengaruhi mutu pendidikan Taman Kanak-kanak (TK) di Kota Banjarbaru. Tujuan penelitian ini adalah untuk melihat bagaimana pengaruh motivasi berprestasi dan gaya kepemimpinan kepala sekolah terhadap mutu pendidikan taman kanak-kanak di Kota Banjarbaru. Penelitian ini termasuk ke dalam jenis penelitian kuantitatif deskriptif dengan menggunakan rancangan survey. Sampel diambil melalui Proportionate stratifified Random sampling sebanyak 30 dari 149 TK se- Kota Banjarbaru yang diklasifikasikan berdasarkan satuan TK akreditasi dan belum akreditasi. Teknik pengumpulan data melalui angket skala lima kategori Likert. Teknik analisis data yang digunakan adalah korelasi pearson product moment, determinasi, dan regresi. Hasil penelitian diperoleh dengan menunjukan pengaruh yang positif dan signifikan antara motivasi berprestasi dan gaya kepemimpinan kepala sekolah terhadap mutu pendidikan TK. Besarnya pengaruh motivasi berprestasi dan gaya kepemimpinan kepala sekolah terhadap mutu pendidikan TK dapat dijadikan pertimbangan bagi sekolah dalam usaha meningkatkan mutu pendidikan di TK.
\end{abstract}

Kata Kunci : Gaya Kepemimpinan, Motivasi Berprestasi, Mutu Pendidikan

\section{ABSTRACT}

The role of the principal is vital in developing and improving the quality of education in accordance with the standards. Leadership of principals becomes one of the decisive factors in the process of education in schools that can improve the quality of education. Achievement motivation and leadership style of principals are the variables that affect the quality of Kindergarten (KD) education in Banjarbaru City. The purpose of this study is to see how the influence of achievement motivation and leadership style of principals to the quality of kindergarten education in the city of Banjarbaru. This research belongs to a descriptive quantitative research type using survey design. Samples were taken through Proportionate stratifified random sampling of 30 out of 149 kindergartens of Banjarbaru City which were classified based on unaccredited and not accreditation kindergarten. Data collection techniques through a five-scale questionnaire Likert category. Data analysis technique used is Pearson product moment correlation, determination, and regression. The results obtained by showing a positive and significant influence between achievement motivation and leadership style of the principal on the quality of kindergarten education. The magnitude of the influence of achievement motivation and leadership style of the principal on the quality of kindergarten education can be considered for the school in an effort to improve the quality of education in kindergarden.

Keywords: Achievement Motivation, Leadership Style, Quality of Education

\section{PENDAHULUAN}

Pola pikir dan pola tindak yang kreatif perlu dilatih dan dibiasakan sejak usia dini, karena pada usia dini anak mengalami masa keemasan (the golden years), dimana anak-anak usia tersebut sangat peka terhadap pengaruh dan perubahan yang berasal dari lingkungan sekitarnya. (Sujiono and Sujiono, 2010). Peran lingkungan sangat mempengaruhi pertumbuhan dan perkembangan anak. Menurut Yus (2015) mengemukakan bahwa masa anak merupakan masa terjadinya peningkatan perkembangan kecerdasan dari $50 \%$ menjadi $80 \%$, dimana peningkatan terjadi secara optimal jika lingkungan memberikan rangsangan atau stimulan yang tepat, tentunya hanya dapat diperoleh dari lingkungan yang baik dan bermutu sesuai kebutuhan pertumbuhan dan perkembangan anak.

Selain lingkungan keluarga, salah satu lingkungan yang dapat membantu stimulasi pertumbuhan dan perkembangan anak yaitu melalui pendidikan anak usia dini (PAUD). Taman 
kanak-kanak (TK) merupakan satuan pendidikan anak usia dini (PAUD) di jalur pendidikan formal sesuai dengan Pasal 28 Undang-undang Republik Indonesia Nomor 20 Tahun 2003 tentang Sistem Pendidikan Nasional. TK melayani pendidikan anak usia 4 s.d 6 tahun, yang dikelompokan berdasarkan usia yaitu, Kelompok A untuk anak usia 4 s.d 5 tahun, dan Kelompok B untuk anak usia 5 s.d 6 tahun. Pada usia ini pertumbuhan dan perkembangan anak dapat di identifikasi meliputi berbagai hal, pengembangan kemampuan anak pada taman kanak-kanak diantaranya meliputi pengembangan fisik, bahasa, kognitif, sosioemosional, seni dan pengembangan moral dan nilai-nilai agama. (Yus, 2015).

Untuk mengoptimalkan pertumbuhan dan perkembangan anak usia 4 s.d 6 tahun, maka taman kanak-kanak harus dikelola secara profesional dan bermutu agar menghasilkan sumber daya manusia yang berkualitas dimasa yang akan datang. Untuk meraih hasil mutu yaitu dengan upaya - upaya yang dapat memperlihatkan standar-standar tinggi. (Sallis, 2012). Taman kanak-kanak yang bermutu salah satunya adalah yang dapat memenuhi standar nasional pendidikan anak usia dini yang sudah ditetapkan oleh Pemerintah. Sebagaimana dikatakan sallis dalam (Engkoswara and Komariah, 2012) menyebutkan bahwa standar mutu dapat dilihat dari dua sisi yaitu (1) standar produk atau jasa yang ditunjukan dengan kesesuaian dengan spesifikasi yang ditetapkan, dan standar yang ditujukan dengan adanya kepuasan pelanggan.

Dalam capaian peningkatan mutu sesuai standar nasional pendidikan, maka perlu adanya penumbuhan budaya peningkatan mutu bekelanjutan atau Perbaikan mutu terus menerus (Continous Quality Improvement). (Satori, 2016). Sedangkan dalam konteks pendidikan taman kanak-kanak, mutu pendidikan taman kanak dapat didefinisikan sebagai kesesuaian penyelenggaraan pendidikan taman kanak-kanak dengan memenuhi dan melebihi standar mutu pendidikan anak usia dini dan kepuasan terhadap keinginan dan kebutuhan orang tua siswa, dengan selalu melakukan perbaikan mutu terus - menerus (Continous Quality Improvement).

Beberapa tahun terakhir perkembangan Pendidikan anak usia dini (PAUD) semakin meningkat yang ditandai dengan meningkatnya Angka Partisipasi Kasar (APK) PAUD di Indonesia yang pada tahun 2013 berada pada 65,16 dan pada tahun 2017, meningkat menjadi 72,35. Ini menandakan bahwa pemerintah dan masyarakat telah sadar betapa pentingnya pendidikan anak usia dini. Arah kebijakan pemerintah dapat menentukan arah tujuan pendidikan nasional, tidak tekecuali pendidikan Taman kanak-kanak. Dengan adanya kebijakan dan bantuan pemerintah dapat memicu dan mendorong perkembangan satuan pendidikan Taman kanak-kanak di daerah-daerah sehingga anak usia 4 s.d 6 tahun dapat terlayani. Temuan yang diperoleh menunjukan bahwa mengenai hubungan antara stabilitas politik pemerintahan dengan sistem pendidikan nasional, yang menunjukkan bahwa stabilitas politik pemerintah adalah prediktor yang berguna sebesar $52 \%$ (persen) dari kualitas pendidikan yang diukur dengan tingkat kelangsungan hidup yang mencirikan sistem pendidikan nasional. (Nir and Kafle, 2013). Perumusan kebijakan ini telah memberi sinyal kebutuhan akan kepala sekolah dan meningkatkan kapasitas kepemimpinan dalam organisasi pendidikan anak usia dini dan mengeksplorasi strategi kepemimpinan yang efektif. (Heikka, Waniganayake and Hujala, 2013). Menurut Suryana (2007) dalam B. S. Prabowo (2012) menegaskan bahwa pencapaian 
mutu sekolah melalui kegiatan akreditasi diarahkan pada peningkatan kualitas sekolah, melihat dan memperoleh gambaran kinerja sekolah yang sebenarnya, sebagai alat pembinaan, pengembangan, dan peningkatan mutu pendidikan di sekolah, kelayakan sekolah dalam penyelenggaraan dan pelayanannya, serta memberikan gambaran menyeluruh bagi masyarakat tentang tingkat sekolah dimana anaknya berada dengan sekolah-sekolah lainnya. Tetapi pada kenyataannya, banyak PAUD di kota Banjarbaru yang belum terakreditasi, ini dapat dilihat dari data yang dikeluarkan oleh Badan Akreditasi Nasional (BAN) PAUD PNF, adapun hasil akreditasi satuan pendidikan anak usia dini di kota Banjarbaru yang masih berlaku sampai dengan tahun 2017 yaitu sebanyak 97 TK belum terakreditasi. Sedangkan taman kanak-kanak yang sudah terakreditasi baru 86 TK dari 149 TK yang ada di Kota Banjarbaru atau 35\% yang terakreditasi. (Dapodik PAUD Kota Banjarbaru, 2017/2018).

Masih sedikit TK yang terakreditasi, ini menunjukan bahwa kurangnya kesadaran satuan pendidikan TK tentang mutu pendidikan taman kanak-kanak yang sesuai dengan standar nasional pendidikan anak usia dini dan dapat diindentifikasikan sebagai kurangnya motivasi berprestasi kepala sekolah taman kanak-kanak dalam mewujudkan TK yang bermutu. Sebagaimana dalam hasil penelitian menunjukan bahwa motivasi berprestasi kepala sekolah pada sekolah yang terakreditasi A dalam kategori sangat tinggi. (Ekada, Mirfani and Sutarsih, 2016).

Motivasi berprestasi kepala sekolah merupakan dorongan dari dalam diri kepala sekolah untuk melakukan segala kegiatan atau tugas dengan sebaik-baiknya untuk dapat meraih kesuksesan atau prestasi kerja yang gemilang.
(Wau, 2014). Prestasi kerja yang gemilang dapat di interprestasikan sebagai nilai terbaik dari hasil akreditasi, dan hasil akreditasi dengan nilai terbaik merupakan gambaran mutu dari sekolah. Dalam teori motivasi berprestasi yang dikemukakan oleh David McClelland (1961, 1965, 1985) dalam Hoy and G.Miskel (2014) disebut juga dengan teori pencapaian kebutuhan, yaitu memenuhi kebutuhan akan berprestasi untuk menyelesaikan pekerjaan/ tugas yang berat, mengatasi segala kesulitan dan hambatan secara kolektif, dan menjadi pribadi yang unggul. Sehingga secara teori, motivasi berprestasi pada individu berusaha untuk unggul dalam apa yang mereka lakukan dan secara aktif berusaha untuk mencapai tujuan yang diinginkan. (Neigel et al., 2017). Motivasi berprestasi adalah dorongan dalam memenuhi kebutuhan akan prestasi, berafiliasi dan kebutuhan akan kekuasaan agar dapat menjadi yang terbaik dan mengungguli orang lain. (Agus Ekada, Aceng Muhtaram Mirfani, Cicih Sutarsih, 2016), David McClelland dalam Mangkunegara (2013).

Seseorang dengan motivasi berprestasi yang tinggi hanya fokus pada prestasi dirinya sendiri, sementara pemimpin yang baik adalah menekankan pada mencapai tujuan bersama-sama. (Robbins and Coulter, 2010). Sekolah Taman kanak-kanak membutuhkan pemimpin yang efektif yang memahami kompleksitas lingkungan global yang berubah dengan cepat. Gaya kepemimpinan kepala sekolah yang berbeda dapat mempengaruhi mutu pendidikan setiap sekolah. (Nanjundeswaras and Swamy, 2014).

Gaya kepemimpinan menurut Engkoswara dan Komariah (2012) dapat diartikan sebagai norma atau pola perilaku dalam memperagakan atau mengimplementasikan kepemimpinannya. Gaya kepemimpinan seorang pemimpin bukan sebuah fenomena satu gaya cocok untuk semua 
melainkan harus dipilih dan disesuaikan agar sesuai dengan individu, organisasi, dan situasi serta tantangan sekarang dan masa depan. (Amanchukwu, Stanley and Ololube, 2015).

Kepala sekolah taman kanak-kanak di kota Banjarbaru umumnya dipimpin oleh seorang perempuan. Berdasarkan perkembangan dalam beberapa dekade terakhir yang menyatakan bahwa gaya transaksional, laissez-faire dan transformasional sangat relevan bagi pemimpin perempuan. (Hard, Press and Gibson, 2013). Beberapa penelitian menunjukkan bahwa untuk kepemimpinan transaksional, wanita memiliki sedikit keunggulan dalam pendekatan berbasis hadiah, sementara pria lebih cenderung menunggu sampai masalah muncul dan baru kemudian mengatasinya. (Gaytán, 2014). Sedangkan hasil temuan Bass, Avolio, dan Atwater (1996) dalam Dhaniarti, Wulandari and Setiawan (2017) yang menemukan bahwa pemimpin perempuan lebih memperlihatkan kepemimpinan transformasional dibanding kan dengan pemimpin laki-laki. Oleh karena itu gaya kepemimpinan transformasional, sering digunakan oleh wanita, dengan efektivitas kepemimpinan yang lebih tinggi dari laki-laki ( Brandt \& Edinger, 2015; Burke \& Collins, 2001;
Eagly et al., 2003; Rincón, González and Barrero, 2017; Van Engen \& Willemsen, 2004).

Sedangkan kepemimpinan yang relevan dengan tuntutan school based management dan diidamkan bagi peningkatan mutu pendidikan dengan fokus pada rekayasa masa depan yang penuh tantangan adalah kepemimpinan yang memiliki visi (visionary leadership). (Sonedi, 2013). Hal ini dikarenakan kepemimpinan visioner dapat dengan cepat beradaptasi terhadap perubahan lingkungan sekitar dan menentukan visi, misi dan tujuan organisasi yang baru sesuai dengan perubahan dan perkembangan jaman,

Gaya kepemimpinan dalam penelitian ini adalah pola perilaku seorang pemimpin dalam mengarahkan orang lain untuk mencapai tujuan, perilaku tersebut menunjukan gaya Transaksional, Transformasional dan Visioner. Engkoswara dan Aan Komariah (2012); Robbins, Stephen. P. (2008); Chi Wai Chan (2014); Gipson et al. (2017). Menurut Veliu et al., (2017) mengungkapkan bahwa gaya kepemimpinan yang berbeda membawa konsekuensi yang berbeda, yang memiliki dampak langsung atau tidak langsung terhadap sikap dan perilaku orang disekitar pemimpin seperti guru, karyawan, orang tua mapun masyarakat dan pemerintah.

\section{METODE PENELITIAN}

Penelitian ini termasuk ke dalam jenis penelitian kuantitatif deskriptif dengan menggunakan metode survey. Sampel diambil melalui Proportionate stratifified Random sampling sebanyak 30 dari 149 TK se- Kota Banjarbaru yang diklasifikasikan berdasarkan satuan TK akreditasi dan belum akreditasi. Teknik pengumpulan data melalui angket skala lima kategori Likert.

Sebelum kuesioner digunakan dalam penelitian ini terlebih dahulu dilakukan uji coba untuk menentukan validitas dan reliabilitas instrumen. Hasil tersebut digunakan sebagai instrumen untuk mengambil data dalam penelitian di lapangan. Analisis data meliputi: 1) deskripsi data; 2) uji prasyarat analisis: uji normalitas, homogenitas dan linieritas; 3) pengujian hipotesis dengan penentuan tingkat pengaruh melalui analisis korelasi, taraf signifikansi, analisis koefisien determinasi, dan analisis regresi. Deskripsi setiap variabel dapat digambarkan dari skor rata-rata yang diperoleh dengan menggunakan 
teknik Weighted Mean Scored (WMS). Teknik ini digunakan untuk mendapatkan kecenderungan skor yang diberikan oleh responden pada setiap item pernyataan sesuai dengan kriteria atau tolak ukur yang digunakan peneliti.(Falimu, 2017).

Untuk menentukan kriteria atau kategori jawaban yang diperoleh, maka hasil perhitungan akan dikonversikan dengan kriteria penafsiran berdasarkan rata-rata skor variabel, sebagai berikut.

Tabel 1

Kriteria Penafsiran Weighted Mean Scored (WMS)

\begin{tabular}{|c|c|c|}
\hline $\begin{array}{c}\text { Rentang } \\
\text { Skor }\end{array}$ & $\begin{array}{c}\text { Pilihan } \\
\text { Jawaban }\end{array}$ & Kriteria \\
\hline $4,21-5,00$ & Selalu & $\begin{array}{l}\text { Sangat Tinggi/ Sangat } \\
\text { Baik }\end{array}$ \\
\hline $\begin{array}{l}3,41-4,20 \\
2,61-3,40\end{array}$ & $\begin{array}{l}\text { Sering } \\
\text { Kadang- }\end{array}$ & $\begin{array}{c}\text { Tinggi/ Baik } \\
\text { Sedang/Cukup Baik }\end{array}$ \\
\hline $\begin{array}{l}1,81-2,60 \\
1,00-1,80\end{array}$ & $\begin{array}{c}\text { kadang } \\
\text { Jarang } \\
\text { Tidak } \\
\text { Pernah }\end{array}$ & $\begin{array}{c}\text { Rendah/ Kurang Baik } \\
\text { Sangat Rendah/ Tidak } \\
\text { Baik }\end{array}$ \\
\hline
\end{tabular}

Sumber: (Khoerudin, Hernawan and Purnamasari, 2017)

Sedangkan untuk mengartikan nilai korelasi (r) product moment, dapat dilihat dari tabel interpretasi sebagai berikut:

Tabel 2

Pedoman dalam menginterprestasikan koefisien korelasi Nilai $r$

\begin{tabular}{cc}
\hline Interval Koefisien & Tingkat Hubungan \\
\hline $0,80-1,000$ & Sangat Kuat \\
$0,60-0,799$ & Kuat \\
$0,40-0,599$ & Sedang \\
$0,20-0,399$ & Rendah \\
$0,00-0,199$ & Sangat Rendah
\end{tabular}

Sumber : (Sugiyono, 2015, hlm. 231).

Pengolahan dan analisis data yang dilakukan peneliti menggunakan bantuan aplikasi khusus pengolah data yaitu aplikasi Statistical Package for the Social Sciens (SPSS) Statistic Desk-top 22.0 for windows and Macinthos (www.spss.com).

\section{HASIL PENELITIAN}

Analisis deskriptif setiap variabel penelitian dilakukan untuk memberikan gambaran secara rinci mengenai motivasi berprestasi, gaya kepemimpinan kepala sekolah dan mutu pendidikan Taman kanak-kanak di Kota Banjarbaru. Adapun skor rata-rata setiap variabel penelitian dapat dilihat pada gambar 1 berikut:

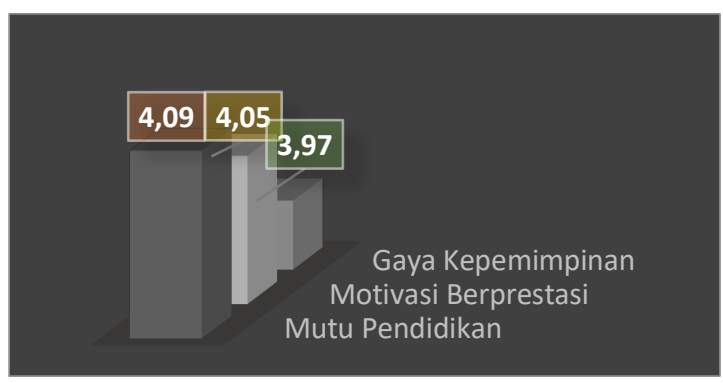

Grafik 1 Skor Rata-Rata Setiap Variabel Penelitian

Hasil perhitungan rata-rata variabel mutu pendidikan Taman kanak-kanak yaitu sebesar 4,09. Jika dikonversikan dengan tabel Kriteria Penafsiran Weighted Mean Scored (WMS) maka nilai rata-rata skor tersebut masuk ke dalam kategori tinggi, perhitungan hasil penelitian memberikan informasi bahwa motivasi berprestasi kepala sekolah Taman kanak-kanak di Kota Banjarbaru teridentifikasi berada pada kriteria tinggi dengan skor rata-rata 4,05. Sedangkan nilai rata-rata variabel gaya kepemimpinan kepala sekolah menunjukan skor sebesar 3.97, data perhitungan hasil penelitian memberikan informasi bahwa gaya kepemimpinan kepala sekolah Taman kanak-kanak di Kota Banjarbaru teridentifikasi berada pada kriteria tinggi.

Hasil perhitungan rata-rata variabel mutu pendidikan Taman kanak-kanak merupakan nilai rata-rata hasil perhitungan dari dimensi kesesuai dengan standar PAUD dan Perbaikan mutu terus menerus (Continous Quality Improvement). Adapun nilai rata-rata dimensi tertinggi yaitu dimensi Kesesuaian dengan standar PAUD dengan 
skor rata-rata 4,23 dalam kategori sangat tinggi. Sedangkan dimensi Perbaikan mutu terus menerus (Continous Quality Improvement) memilki skor 3,95. Jika di konversikan ke dalam tabel hasil perhitungan WMS, maka skor tersebut masuk dalam kriteria tinggi. Untuk melihat secara visual penyebaran skor rata-rata dimensi dari variabel mutu pendidikan Taman kanak-kanak dapat dilihat pada gambar 2 berikut:

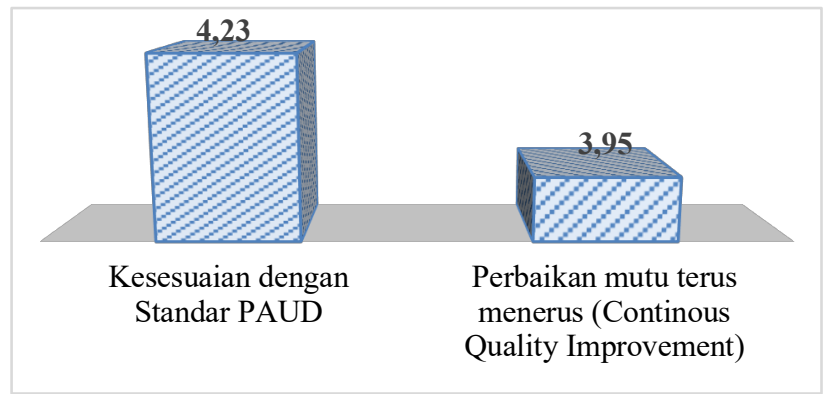

Grafik 2

Skor Rata-rata Dimensi pada Variabel Mutu Pendidikan

Data perhitungan hasil penelitian memberikan informasi bahwa motivasi berprestasi kepala sekolah Taman kanak-kanak di Kota Banjarbaru teridentifikasi berada pada kriteria tinggi. Variabel motivasi berprestasi kepala sekolah dijabarkan ke dalam 3 (tiga) dimensi. Hasil perhitungan dimensi variabel motivasi berprestasi kepala sekolah jika diurutkan berdasarkan peringkat, maka diperoleh hasil bahwa dimensi kebutuhan akan afiliansi berada pada peringkat pertama dengan skor rata-rata 4,15 (tinggi) dan diposisi peringkat kedua ada dimensi kebutuhan akan prestasi yaitu dengan skor rata-rata 4.01 (tinggi). Sementara dimensi kebutuhan akan kekuasaan berada pada posisi paling rendah dengan memiliki skor rata-rata 3.98 (tinggi). Skor rata-rata dimensi variabel motivasi berprestasi kepala sekolah dapat dilihat pada gambar 3 berikut:

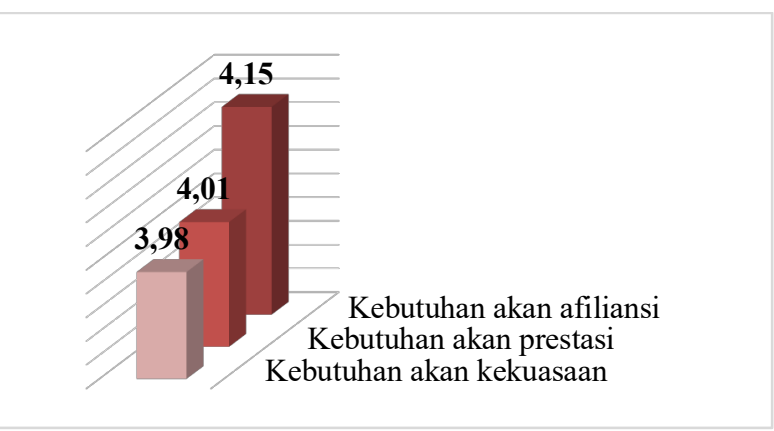

Grafik 3

Skor Rata-rata Dimensi pada Variabel Motivasi Berprestasi

Sedangkan hasil perhitungan dimensi variabel gaya kepemimpinan kepala sekolah, jika diurutkan berdasarkan peringkat, maka diperoleh hasil bahwa dimensi gaya visioner berada pada peringkat pertama dengan skor rata-rata 4.03 (tinggi) dan diposisi peringkat kedua ada dimensi gaya transformasional yaitu dengan skor rata-rata 3.99 (tinggi). Sementara dimensi gaya transaksional berada pada posisi paling rendah dengan memiliki skor rata-rata 3.91 (tinggi). Skor rata-rata dimensi variabel gaya kepemimpinan kepala sekolah dapat dilihat pada gambar 4 berikut:

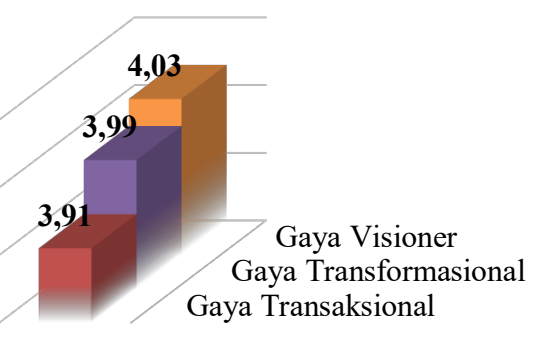

\section{Grafik 4}

Skor Rata-rata Dimensi pada Variabel Gaya

Kepemimpinan Kepala Sekolah

Ada beberapa syarat yang harus dipenuhi sebelum melakukan Pengujian Hipotesis yaitu harus melakukan pengujian persyaratan analisis yaitu dengan uji normalitas, homogenitas, dan lineritas. Dari perhitungan uji persyaratan analisis diperoleh hasil bahwa data penelitian berdistribusi normal, homogen dan berpola linear. Hasil pengujian persyaratan analisis tersebut menunjukkan bahwa skor setiap variabel penelitian telah memenuhi syarat untuk dilakukan pengujian 
statistik lebih lanjut. Pengujian hipotesis penelitian dilakukan dengan menghitung koefesien korelasi, taraf signifikansi, koefisien determinasi, dan analisis regresi. Berdasarkan hasil pengujian hipotesis tersebut diperoleh hasil sebagaimana dalam tabel 3 berikut:

Berdasarkan Tabel 3, dapat diketahui bahwa besarnya pengaruh motivasi berprestasi (X1) terhadap mutu pendidikan Taman kanakkanak (Y) adalah sebesar 0,836. Nilai tersebut menunjukan bahwa terdapat hubungan yang sangat kuat antara motivasi berprestasi terhadap mutu pendidikan Taman kanak-kanak di Kota Banjarbaru. Sedangkan besar kontribusi yang diberikan motivasi berprestasi terhadap mutu pendidikan Taman kanak-kanak adalah sebesar 0,698. Artinya variabel motivasi berprestasi

memberikan kontribusi terhadap mutu pendidikan sebesar 69,8\%. Sedangkan sisanya 30,2\% dtentukan oleh variabel lain. Persamaan regresi sederhana dari motivasi berprestasi (X1) terhadap mutu pendidikan Taman kanak-kanak (Y) yaitu: $\mathrm{Y}=64,349+1,154 \mathrm{X} 1$. Dari persamaan tersebut dapat diketahui bahwa: 1). Motivasi berprestasi mempunyai pengaruh yang positif terhadap mutu pendidikan, yaitu sebesar 1,154, yang artinya semakin tinggi motivasi berprestasi maka akan semakin baik mutu pendidikan Taman kanakkanak. 2). Nilai konstanta sebesar 64,349, yang artinya jika tidak ada motivasi berprestasi atau sama dengan nol, maka mutu pendidikan Taman kanak-kanak sebesar 64,349 dengan asumsi variabel-variabel lain yang dapat mempengaruhi tetap.

Tabel 3

Rangkuman Hasil Pengujian Hipotesis

Variabel Motivasi Berprestasi $\left(\mathrm{X}_{1}\right)$, Gaya Kepemimpinan $\left(\mathrm{X}_{2}\right)$, dan Mutu Pendidikan (Y)

\begin{tabular}{|c|c|c|c|c|c|c|c|}
\hline $\begin{array}{c}\text { Pengaruh } \\
\text { antar } \\
\text { variabel }\end{array}$ & $\begin{array}{c}\text { Koefisien } \\
\text { r dan } R\end{array}$ & $\begin{array}{l}\text { Nilai } \\
\text { Seg. }\end{array}$ & $\begin{array}{c}\text { Koefesien } \\
\text { Determinasi } \\
\text { (R Square) }\end{array}$ & $\begin{array}{c}\text { Kontribusi } \\
\text { Varibel } \\
\text { Penelitian } \\
\end{array}$ & $\begin{array}{c}\text { Kontribusi } \\
\text { Variabel } \\
\text { Lain } \\
\end{array}$ & Nilai Persamaan Regresi & $\begin{array}{c}\text { Hasil } \\
\text { Pengujian }\end{array}$ \\
\hline $\begin{array}{c}\mathrm{X} 1 \\
\text { terhadap Y }\end{array}$ & 0,836 & 0,000 & 0,698 & $69,8 \%$ & $30,2 \%$ & $Y=64,349+1,154 X_{1}$ & $\begin{array}{c}\text { Positif dan } \\
\text { siginikan }\end{array}$ \\
\hline $\begin{array}{c}\mathrm{X} 2 \\
\text { terhadap } \mathrm{Y}\end{array}$ & 0,807 & 0,000 & 0,651 & $65,1 \%$ & $34,9 \%$ & $Y=96,036+0,889 X_{2}$ & $\begin{array}{c}\text { Positif dan } \\
\text { siginikan }\end{array}$ \\
\hline $\begin{array}{l}\mathrm{X} 1 \text { dan } \mathrm{X} 2 \\
\text { terhadap } \mathrm{Y}\end{array}$ & 0,840 & 0,000 & 0,706 & $70,6 \%$ & $29,4 \%$ & $Y=65,344+0,855 X_{1}+0,258 X_{2}$ & $\begin{array}{c}\text { Positif dan } \\
\text { siginikan }\end{array}$ \\
\hline
\end{tabular}

Besarnya pengaruh gaya kepemimpinan kepala sekolah (X2) terhadap mutu pendidikan Taman kanak-kanak (Y) adalah sebesar 0,807. Nilai tersebut menunjukan bahwa terdapat hubungan yang sangat kuat antara gaya kepemimpinan kepala sekolah terhadap mutu pendidikan Taman kanak-kanak di Kota Banjarbaru. Sedangkan besar kontribusi yang diberikan gaya kepemimpinan kepala sekolah terhadap mutu pendidikan Taman kanak-kanak adalah sebesar 0,651. Artinya variabel gaya kepemimpinan memberikan kontribusi terhadap mutu pendidikan sebesar 65,1\%. Sedangkan sisanya $34,9 \%$ ditentukan oleh variabel lain.
Persamaan regresi sederhana dari gaya kepemimpinan kepala sekolah (X2) terhadap mutu pendidikan Taman kanak-kanak (Y) yaitu: $\mathrm{Y}=$ $96,036+0,889 X 2$. Dari persamaan tersebut dapat diketahui bahwa: 1). Gaya kepemimpinan kepala sekolah mempunyai pengaruh yang positif terhadap mutu pendidikan, yaitu sebesar 0,889, yang artinya semakin tinggi gaya kepemimpinan kepala sekolah maka akan semakin baik mutu pendidikan Taman kanak-kanak. 2). Nilai konstanta sebesar 96,036, yang artinya jika tidak ada gaya kepemimpinan kepala sekolah atau sama dengan nol, maka mutu pendidikan Taman kanak- 
kanak sebesar 96,036, dengan asumsi variabelvariabel lain yang dapat mempengaruhi tetap.

Besarnya pengaruh motivasi berprestasi dan gaya kepemimpinan kepala sekolah secara bersama-sama terhadap mutu pendidikan Taman kanak-kanak adalah sebesar 0,840 . Nilai tersebut menunjukan bahwa terdapat hubungan yang sangat kuat antara motivasi berprestasi dan gaya kepemimpinan kepala sekolah secara simultan terhadap mutu pendidikan Taman kanak-kanak di Kota Banjarbaru. Sedangkan besar kontribusi yang diberikan motivasi berprestasi dan gaya kepemimpinan kepala sekolah secara simultan terhadap mutu pendidikan Taman kanak-kanak adalah sebesar 0,706. Artinya variabel motivasi berprestasi dan gaya kepemimpinan kepala sekolah secara simultan memberikan kontribusi terhadap mutu pendidikan sebesar 70,6\%. Sedangkan sisanya 29,4\% ditentukan oleh variabel lain.

Besar kontribusi pada desain penelitian dapat digambarkan sebagai berikut:

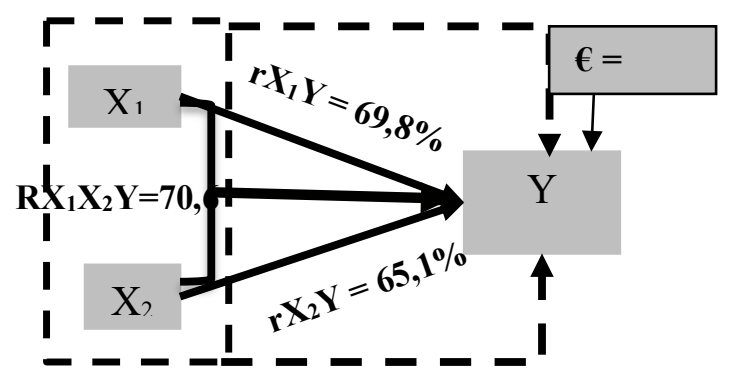

Gambar 1

Hasil koefisien korelasi antar variabel bebas dan terikat
Persamaan regresi ganda dari motivasi berprestasi (X1) dan gaya kepemimpinan kepala sekolah (X2) secara simultan terhadap mutu pendidikan Taman kanak-kanak (Y) yaitu: $\mathrm{Y}=$ $65,344+0,855 \mathrm{X} 1+0,258 \mathrm{X} 2$. Dari persamaan tersebut dapat diketahui bahwa: 1). Motivasi berprestasi dan gaya kepemimpinan kepala sekolah secara simultan mempunyai pengaruh yang positif terhadap mutu pendidikan, dengan besar $\mathrm{X} 1$ yaitu sebesar 0,855 dan X2 sebesar 0,258, yang artinya mutu pendidkan Taman kanak-kanak lebih dipengaruhi oleh motivasi berprestasi dari pada gaya kepemimpinan kepala sekolah. Jika motivasi berprestasi ditingkatkan 1 kali dan gaya kepemimpinan sama dengan nol (0), maka mutu pendidikan Taman kanak-kanak akan meningkat sebesar 0,855 . Dan jika gaya kepemimpinan kepala sekolah yang ditingkatkan sebesar 1 kali, maka mutu pendidikan Taman kanak-kanak akan meningkat sebesar 0,258. 2). Nilai konstanta sebesar 65,344, yang artinya jika tidak ada motivasi berprestasi dan gaya kepemimpinan kepala sekolah atau X1 dan X2 sama dengan nol, maka mutu pendidikan Taman kanak-kanak sebesar 65,344, dengan asumsi variabel-variabel lain yang dapat mempengaruhi tetap.

\section{PEMBAHASAN}

Mutu Pendidikan Taman Kanak-kanak di

\section{Kota Banjarbaru}

Berdasarkan hasil perhitungan dan analisis deskripsi data penelitian, informasi yang diperoleh bahwa secara umum mutu pendidikan Taman kanak-kanak di Kota Banjarbaru tergolong kedalam kategori tinggi. Sehingga Kota
Banjarbaru telah memiliki sekolah Taman kanakkanak yang bermutu tinggi. Hal ini di dukung oleh ketercapaian dalam memenuhi standar nasional pendidikan anak usia dini yang sudah termasuk kedalam kategori sangat tinggi. Meskipun dalam memenuhi ketercapaian standar mutu PAUD telah berada pada kategori sangat tinggi tetapi masih 
belum mampuh maksimal dalam melakukan perbaikan mutu terus menerus (Continous Quality Improvement). Berdasarkan data empirik, mutu pendidikan taman kanak-kanak di kota Banjarbaru berada pada kategori sangat tinggi pada aspek ketercapaian standar mutu pendidikan anak usia dini, ini dapat diartikan bahwa standar nasional pendidikan yang ditetapkan pemerintah menjadi rujukan bagi setiap kepala sekolah dalam mengkaji pencapaian pendidikan, penjaminan dan peningkatan mutu pendidikan taman kanak-kanak. (Satori, 2016). Dengan adanya standar nasional pendidikan, maka kepala sekolah sudah memiliki arah dan tujuan yang jelas dalam menyelenggarakan taman kanak-kanak yang bermutu. Tetapi standar nasional pendidikan bukanlah akhir dari ketercapaian mutu pendidikan, sehingga dibutuhkan proses penjaminan mutu yang berkelanjutan secara berkala atau bertahap sebagai kelangsungan hidup satuan pendidikan taman kanak-kanak dalam menghadapi perkembangan zaman atau globalisasi yaitu dengan selalu melakukan perbaikan mutu terus menerus (Continous Quality Improvement). (Satori, 2016).

Dalam sistem pendidikan Indonesia berorientasi pada standar mutu sebagai penjaminan terhadap mutu pendidikan secara nasional dengan selalu melakukan peningkatan mutu pendidikan secara terencana dan berkala atau terus-menerus. (Saepudin, 2017).

Hasil temuan menunjukan bahwa masih belum mampu memaksimalkan dalam melakukan perbaikan mutu terus menerus (Continous Quality Improvement) dimana masih berada dibawah dari ketercapaian terhadap standar mutu. Perbaikan mutu terus menerus (Continous Quality Improvement) sangat penting dalam proses penjaminan mutu dan peningkatan mutu pendidikan. Ada beberapa masalah umum yang ada dalam melakukan evaluasi standar mutu seperti membayar lebih banyak perhatian pada hasil daripada proses, lebih pada kesamaan daripada pada perbedaan, lebih pada kondisi sekarang daripada mutu selanjutnya (Qian, 2012), sehingga perlu adanya pengembangan yang berkala dan berkelanjutan terhadap standar mutu nasional. Taman kanak-kanak yang melakukan pengembangan dan inovasi secara konstan, melakukan perbaikan dan perubahan ke arah yang baik akan mengalami siklus perbaikan secara terus - menerus. (Sallis, 2012). Hal ini juga disampaikan oleh Flanagan and Associates (2018) bahwa Perbaikan mutu terus menerus (Continous Quality Improvement) merupakan sebuah siklus yang proaktif dan tidak reaktif, dengan selalu melakukan perbaikan kearah positif bahkan ketika semuanya berjalan dengan baik, sehingga tidak menunggu sesuatu yang salah dan kemudian memperbaikinya. Indikator terendah dalam mendukung perbaikan mutu terus menerus (Continous Quality Improvement) adalah melibatkan semua pihak dalam melakukan perbaikan, hal ini menunjukan bahwa kurangnya keterlibatan pendidik, tenaga kependidikan, orang tua, masyarakat dan pemerintah dalam melakukan perbaikan mutu terus menerus (Continous Quality Improvement). Padahal menurut Sallis (2012) dalam menjalankan perbaikan mutu terus menerus terutama dalam menciptakan budaya mutu di sekolah harus melibatkan segenap komponen sekolah, sehingga seluruh kompenen sekolah memiliki rasa tanggung jawab dalam pemecahan masalah dan pengambilan keputusan untuk meningkatkan mutu dalam lingkungan sekolah mereka. Dalam proses pendidikan yang efektif membutuhkan kolaborasi dan komitmen dari semua komponen sekolah dan refleksi diri dengan meningkatkan kompetensi yang terlibat dalam penjaminan mutu melalui 
proses perbaikan mutu berkelanjutan. (Muthanna, 2015).

\section{Motivasi Berprestasi Kepala Sekolah di Kota Banjarbaru}

Berdasarkan hasil perhitungan dan analisis deskripsi data penelitian, informasi yang diperoleh bahwa secara umum Motivasi berprestasi kepala sekolah taman kanak-kanak di Kota Banjarbaru tergolong kedalam kategori tinggi. Hal ini menunjukan bahwa kepala sekolah taman kanakkanak di Kota Banjarbaru memiliki motivasi berprestasi yang tinggi yang berkenaan dengan aspek kebutuhan akan prestasi, afiliansi dan kekuasaan. Motivasi berprestasi memiliki hubungan penting dari tiga motivasi kebutuhan yaitu achievement, affiliation, and power dalam mencapai tujuan prestasi atau pencapaian. (Bipp and Dam, 2014).

Motivasi kepala sekolah dipengaruhi oleh kekuatan intrinsik yang ada pada diri individu yang bersangkutan, pengaruh eksternal mungkin juga dapat mempengaruhi motivasi, tetapi motivasi itu sendiri mencerminkan reaksi individu terhadap pengaruh tersebut. Motivasi merupakan dorongan yang menggerakan seseorang untuk melakukan sesuatu atau berprilaku untuk meraih tujuan tertentu. Dengan tetap menjaga motivasi dalam diri maka akan mudah mencapai kesuksesan. (Kroth, 2007). Motivasi berprestasi adalah dorongan dalam memenuhi kebutuhan akan prestasi, berafiliansi dan kebutuhan akan kekuasaan agar dapat menjadi yang terbaik dan mengungguli orang lain. Dengan adanya tujuan untuk berprestasi diharapkan kepala sekolah memiliki motivasi yang kuat untuk meningkatkan mutu pendidikan. motivasi berprestasi personal dan kontekstual merupakan aspek yang berguna untuk dipertimbangkan terutama ketika intervensi dalam pengaturan pencapaian dirancang untuk meningkatkan kualitas motivasi dan hasil yang dicapai. (Michou et al., 2016).

Berdasarkan temuan penelitian, aspek pendukung tertinggi dalam variabel motivasi berprestasi adalah kebutuhan akan afiliasi, sedangkan aspek kebutuhan akan prestasi berada pada aspek pendukung kedua dan aspek pendukung terendah adalah aspek kebutuhan akan kekuasaan. Menurut Jha (2010) mengatakan bahwa dari sudut pandang dalam membuat keputusan penting, kebutuhan afiliasi yang rendah mungkin lebih baik karena disertai dengan kekhawatiran minimal tentang disukai. Lebih lanjut Jha (2010) menjelaskan bahwa dalam kepemimpinan yang efektif harus memiliki kebutuhan yang tinggi dalam kekuasaan, karena kepala sekolah dengan kebutuhan tinggi akan kekuasaan memiliki cara yang lebih aktif, tegas dan mengendalikan dalam interaksi kepala sekolah dengan orang lain serta memiliki dampak pada orang lain dan cukup terbuka untuk membangun reputasi, posisi, dan otoritas kepala sekolah.

\section{Gaya Kepemimpinan Kepala Sekolah di Kota Banjarbaru}

Berdasarkan hasil perhitungan dan analisis deskripsi data penelitian, informasi yang diperoleh bahwa secara umum gaya kepemimpinan kepala sekolah taman kanak-kanak di Kota Banjarbaru tergolong kedalam kategori tinggi. Hal ini menunjukan bahwa kepala sekolah taman kanakkanak di Kota Banjarbaru memiliki gaya kepemimpinan yang tinggi yang berkenaan dengan aspek gaya transaksional, transformasional, dan visioner. Dimana Kepemimpinan lebih merupakan hasil kerjasama antara individu yang memanifestasikan dirinya dalam tujuan bersama anggota organisasi lain, penyelarasan perilaku mereka, dan komitmen bersama mereka terhadap 
praktik tertentu. (von Krogh, Nonaka and Rechsteiner, 2012).

Kepemimpinan adalah kegiatan atau seni untuk mempengaruhi perilaku manusia baik perorangan atau kelompok (Thoha, 2015). Untuk itu setiap pemimpin memiliki cara dan gaya masing-masing dalam menjalankan kepemimpinanya. Dimana kebanyakan gaya kepemimpinan mengacu pada sejauh mana pemimpin memusatkan perhatian pada kenyamanan, kesejahteraan, rasa hormat, kebutuhan dan kepuasan orang lain. (Jeremy Mitonga-Monga, Coetzee and Cilliers, 2012). Kepemimpinan kepala sekolah taman kanak-kanak bukan hanya memperhatikan para bawahannya saja seperti guru dan pegawai sekolah, melainkan lingkungan sekitarnya baik orang tua siswa, masyarakat, pemerintah maupun organisasi lainnya agar tujuan organisasi dapat tercapai dengan baik. Sehingga gaya kepemimpinan merupakan pola perilaku seorang pemimpin dalam mengarahkan orang lain untuk mencapai tujuan.

Terkait dengan perubahan positif baik di tingkat individu maupun organisasi, gaya kepemimpinan yang dapat diterapkan yaitu Gaya Visioner, dimana seorang pemimpin mampu menciptakan, merumuskan, mengkomunikasikan/ mentransformasikan dan mengimplementasikan setiap gagasan yang ideal bagi organisasi sebagai cita-cita masa depan yang harus diwujudkan bersama-sama dengan komitmen setiap personil. (Engkoswara dan Komariah, 2012). Gaya transformasional pemimpin dapat memodifikasi keyakinan, nilai, dan minat guru dan pegawai, memotivasi mereka untuk menunjukkan kinerja di luar dugaan. (Pieterse et al., 2009). Gaya transaksional, pada gilirannya, memotivasi bawahan dan orang lain menggunakan proses pertukaran yang menawarkan imbalan tergantung pada pencapaian. (Gözükara, Hatipo and Öncel, 2017).

\section{Pengaruh Motivasi Berprestasi Kepala Sekolah terhadap Mutu Pendidikan Taman Kanak- kanak}

Motivasi berprestasi kepala sekolah memiliki pengaruh signifikan dan bersifat positif terhadap mutu pendidikan taman kanak-kanak. Pengaruh variabel motivasi berprestasi kepala sekolah terhadap mutu pendidikan taman kanakkanak berada pada hubungan dengan kategori yang sangat kuat. Hal ini juga menunjukan bahwa kebutuhan yang lebih tinggi untuk pencapaian dianggap mencerminkan keinginan untuk mengejar standar mutu yang lebih tinggi. (Jha 2010; McClelland, 1965).

Hasil akreditasi merupakan capaian atau prestasi setiap satuan taman kanak-kanak, tidak terkecuali bagi kepala sekolah sendiri, sehingga nilai akreditasi dan pencapaian standar nasional pendidikan dapat dijadikan sebagai dorongan dan tujuan seorang kepala sekolah. Dimana dengan adanya dorongan dan tujuan tersebut menjadikan kepala sekolah memilik motivasi berprestasi. Sebagaimana dikatakan oleh Hariyanto, Muhdi and Abdullah, (2017) bahwa motivasi dapat dipandang sebagai perubahan energi dalam diri seseorang yang ditandai dengan munculnya rasa, gairah, semangat atau dorongan dan didahului dengan tanggapan terhadap adanya tujuan. Sehingga dengan memilik tujuan yang jelas dapat merangsang motivasi berprestasi kepala sekolah. Kepala sekolah yang memiliki motivasi berprestasi tinggi berada pada kemampuan terbaiknya ketika mereka dapat mempertahankan tingkat keterlibatan yang tinggi dalam memastikan keunggulan kegiatan di bawah koordinasi atau kontrol mereka dalam mencapai tujuan. (Norouzi, 2012). Untuk itu seorang kepala sekolah dalam mencapai tujuannya, harus dapat memenuhi kebutuhannya akan prestasi 
dengan menginginkan capaian-capaian yang lebih dari sekarang, dan kebutuhan akan afiliasi untuk dapar bekerjasama dengan berbagai pihak untuk memudahkan dan mempelancar pencapaian tujuan serta memenuhi kebutuhan akan kekuasaan agar semua berada pada koordinasi atau kontrol dan tanggung jawab kepala sekolah.

Hasil penelitian ini juga di dukung oleh penelitian yang dilakukan Kharis, Sudharto and Yuliejantiningsih (2016), yang menyatakan bahwa mutu pendidikan dipengaruhi motivasi berprestasi karena dengan motivasi berprestasi yang tinggi maka timbul semangat untuk melakukan pekerjaan lebih baik dan hasil yang diperoleh dari pekerjaannyapun akan menjadi baik dan bermutu. Hal yang senada juga di sampaikan oleh Sari (2013) yang menyimpulan bahwa makin baik motivasi berprestasi yang diberikan akan membuat mutu pendidikan makin meningkat, hal ini disebabkan motivasi berprestasi sebagai sarana untuk memecahakan masalah bersama antara kepala sekolah dengan guru dan pegawai. Berdasarkan hasil penelitian dan didukung oleh peneliti lain serta teori dan konsep yang ada, maka sangat jelas bahwa motivasi berprestasi kepala sekolah berpengaruh sangat kuat secara positif dan signifikan terhadap mutu pendidikan taman kanakkanak.

\section{Pengaruh Gaya Kepemimpinan Kepala Sekolah terhadap Mutu Pendidikan Taman Kanak- kanak}

Gaya kepemimpinan kepala sekolah memiliki pengaruh positif dan signifikan terhadap mutu pendidikan taman kanak-kanak. Pengaruh gaya kepemimpinan kepala sekolah terhadap mutu pendidikan taman kanak-kanak berada pada hubungan dengan kategori yang sangat kuat dengan arah hubungan adalah positif. Semakin tinggi gaya kepemimpinan kepala sekolah, maka semakin meningkat juga mutu pendidikan taman kanak-kanak. Hal disebabkan karena kepemimpinan menjadi alat penting yang memberikan keunggulan kompetitif untuk setiap sekolah taman kanak-kanak, karena itu membuat guru dan pegawai menjadi efisien dan efektif dalam menjalankan tugasnya. (Amofa, Okronipa and Boateng, 2016).

Berdasarkan data empirik, sangat kuatnya hubungan antara gaya kepemimpinan kepala sekolah terhadap mutu pendidikan taman kanakkanak yaitu adanya kemampuan dan kecakapan kepala sekolah dalam menjalankan peran dan fungsinya sebagai kepala sekolah taman kanakkanak. Hal ini juga menunjukan bahwa kepemimpinan seorang perempuan dalam jabatannya sebagai kepala sekolah tidak jauh berbeda dengan pemimpin laki-laki, atau tidak ada perbedaan dalam kepemimpinan kepala sekolah berdasarkan jenis kelamin. Hasil penelitian yang dilakukan oleh Pavlovic (2015) menunjukan bahwa tidak ada perbedaan antara gaya kepemimpinan kepala sekolah berdasarkan gender, sehingga perlunya mempertahankan partisipasi yang seimbang antara perempuan dan laki-laki selama proses seleksi seorang kepala sekolah.

Gaya kepemimpinan yang berbeda dapat diidentifikasi menurut perilaku kepala sekolah, yaitu bagaimana dia membuat keputusan, bereaksi, dan berinteraksi dengan dan memperlakukan guru dan pegawainya serta orang tua siswa dan masyarakat disekitar. (Chan, 2014). Fakta empirik hasil penelitian memberikan informasi bahwa gaya kepemimpinan kepala sekolah terdiri dari tiga (3) aspek yaitu, gaya transaksional, transformasional dan visoner yang bepengaruh positif dan signifikan terhadap mutu pendidikan taman kanak-kanak di Kota Banjarbaru. Dari ketiga aspek tersebut, gaya Visoner memiliki skor rata-rata tertinggi jika dibandingkan dengan gaya transaksional dan 
transformasional. Hal ini sesuai dengan apa yang disampaikan oleh Hartini (2015) yang mengatakan bahwa gaya visioner merupakan gaya kepemimpinan yang memiliki visi kepemimpinan berdasarkan pemikiran masa depan mengenai organisasi yang merupakan kekuatan kunci bagi perubahan dalam rangka mewujudkan sekolah yang bermutu. Sehingga dalam meningkatkan dan menjaga mutu pendidikan maka seorang kepala sekolah harus memiliki gaya visoner, yang mampu membaca masa depan dan memiliki visi, misi dan tujuan yang jelas terutama dalam pendidikan anak usia dini yang tantangannya semakin berat karena selalu berkembang. Mencegah prestasi rendah dan memaksimalkan potensi, pemeliharaan kepemimpinan prasekolah telah didukung lebih jauh untuk pengembangan gaya visioner yang mampu melalui masa depan yang tidak pasti, Sebagaimana dikatakan Sonedi (2013) Kepemimpinan yang relevan dengan tuntutan manajemen berbasis sekolah dan diunggulkan untuk peningkatan mutu pendidikan adalah kepemimpinan yang memiliki visi (visionary leadership), yaitu kepemimpinan yang kerja pokoknya difokuskan pada rekayasa dan masa depan yang penuh tantangan yang ditandai oleh teknologi maju dan hubungan internasional terutama pasar bebasnya.

Sedangkan gaya transaksional dan transformasional sebagai kepemimpinan pendidikan paling berpengaruh dalam memengaruhi perilaku dan keyakinan guru terhadap diri mereka sendiri (self-efficacy). (Hoxha and Hyseni-duraku, 2017). Gaya transformasional adalah gaya kepemimpinan berorientasi perubahan yang terdiri dari pertimbangan individu (individual consideration), motivasi inspirasional (inspirational motivation), pengaruh ideal (idealized influence) dan rangsangan intelektual (intellectual stimulation). Di sisi lain, gaya transaksional dalam intinya memiliki unsur-unsur pertukaran, antara pemimpin dan pengikut dengan ditandai adanya imbalan/ penghargaan untuk prestasi, Manajemen Eksepsi Aktif (Active Management by Exception), Manajemen Eksepsi Pasif (Passive Management by Exception) dan Bebas (Laissez-Faire), sehingga gaya transaksional merupakan kekuatan untuk melakukan tugas tertentu dan memberi penghargaan atau hukuman sesuai dengan usaha atau kinerja guru dan pegawai. (Alkahtani et al., 2016).

Apapun gaya kepemimpinan yang diadopsi oleh kepala sekolah taman kanak-kanak memiliki implikasi pada variabel sebagai moral kepada guru dan staf dan akibatnya pada mutu pendidikan taman kanak-kanak. (Makura, 2012). Di era transformasi dan komunikasi, seperti pengalaman saat ini dalam pendidikan taman kanak-kanak di kota Banjarbaru, pendekatan kepemimpinan transformasional, yang berfokus pada pentingnya kerjasama tim dan peningkatan sekolah yang komprehensif, akan terus menjadi penting, tetapi hanya sebagai perluasan ke mode lain. Peran kepemimpinan transaksional di mana hubungan didasarkan pada pertukaran nilai akan dilanjutkan dan akan berkembang sebagai kepemimpinan moral yang semakin mengakui fakta bahwa nilai-nilai dan penilaian nilai adalah elemen-elemen sentral dalam mencapai tujuan pendidikan. Para kepala sekolah yang benar-benar ingin meningkatkan mutu pendidikan taman kanak-kanak harus memilki standar kinerja tinggi yang diarahkan kepada pencapaian dan dapat mempengaruhi serta bekerjasama dalam mencapai visi bersama dengan semua unsur baik guru, staf, orang tua siswa, masyarakat dan pemerintah dengan arah dan tujuan yang jelas. Sebagaimana 
dikatakan oleh Botha (2013) menyatakan bahwa gaya transformasional dan transaksional merupakan gaya kepemimpinan pendidikan tradisional, sedangkan rekomendasi baru dalam kepemimpinan pendidikan adalah gaya visionar, hal ini dikarenakan tantangan yang timbul untuk masa depan yaitu mengartikulasikan dan mengimplementasikan visi pendidikan untuk masyarakat kota Banjarbaru yang baru dengan menginginkan peningkatan mutu pendidikan di taman kanak-kanak maka kepala sekolah harus memimpin dengan gaya yang berbeda dari sebelumnya.

Hasil penelitian lain yang dilakukan Sari (2013) mengungkapkan bahwa Gaya kepemimpinan kepala sekolah yang tinggi akan meningkatkan mutu pendidikan, dengan demikian makin tinggi gaya kepemimpinan kepala sekolah akan membuat mutu pendidikan meningkat, hal ini disebabkan pemeliharaan program pengajaran sudah digunakan secara optimal, pencapaian dalam memenuhi standar nasional pendidikan dan selalu melakukan proses perbaikan faktor-faktor yang mempengaruhi pengembangan mutu pendidikan secara berkala dan berkelanjutan. Selain itu, hasil penelitian yang dilakukan oleh Maris, Komariah and Bakar (2016) menunjukkan besarnya pengaruh kepemimpinan kepala sekolah terhadap mutu pendidikan sebesar 0,700 (korelasi kuat), sedangkan pengaruhnya sebesar 49\%. Sedangkan penelitian terdahulu yang dilakukan oleh Hirtz, Murray and Riordan (2007) dan dipublikasikan secara online pada tahun 2015 oleh publisher Taylor \& Francis menyatakan bahwa kepemimpinan memang memiliki pengaruh pada mutu, dan gaya transformasional dan transaksional tertentu lebih efektif.

\section{Pengaruh Motivasi Berprestasi dan Gaya Kepemimpinan Kepala Sekolah terhadap Mutu Pendidikan Taman Kanak-kanak}

Motivasi berprestasi dan gaya

kepemimpinan kepala sekolah secara bersamasama memiliki pengaruh positif dan signifikan dengan kategori sangat tinggi dan kuat terhadap mutu pendidikan taman kanak-kanak. Jika dua aspek pendukung internal yaitu motivasi berprestasi dan gaya kepemimpinan dapat di miliki oleh kepala sekolah secara bersama-sama mendukung pengembangan mutu pendidikan, maka akan menghasilkan korelasi yang sangat kuat. Hasil penelitian yang dilakukan oleh Leaton Gray (2013) yang berpendapat bahwa terjadinya reformasi pendidikan dapat menyebabkan meningkatnya sentralisasi jenis kekuasaan tertentu. Sehingga dalam meningkat mutu pendidikan terutama dalam melakukan perbaikan mutu terus menerus diperlukan adanya perubahan dan reformasi pendidikan yang dilakukan oleh kepala sekolah sebagai agen perubahan dengan meningkatkan kompetensi profesi dan kepribadian kepala sekolah yang di dukung peningkatan kemampuan dan keterampilan bawahan.

Jika dibandingkan dari hasil pengujian hipotesis secara keseluruhan, menunjukan bahwa pengaruh secara bersama-sama lebih kuat dari pada pengaruh masing-masing variabel secara sendirisendiri, artinya peningkatan mutu pendidikan tidak bisa hanya dengan gaya kepemimpinan kepala sekolah saja tetapi motivasi berprestasi juga punya andil paling besar. Sehingga dalam peningkatan dan pengembangan mutu pendidikan memerlukan peningkatan motivasi berprestasi dan gaya kepemimpinan kepala sekolah secara bersamasama.

Hal tersebut didukung dari hasil penelitian yang dilakukan oleh Sari (2013) yang menyatakan bahwa terdapat kontribusi gaya kepemimpinan 
kepala sekolah dan motivasi berprestasi dengan mutu pendidikan dengan memberikan sumbangan yang efektif sebesar $32,2 \%$. Dapat disimpulkan bahwa semakin tinggi dan positif motivasi berprestasi dan gaya kepemimpinan kepala sekolah maka semakin tinggi dan positif pula mutu pendidikan.

\section{SIMPULAN}

Penelitian ini dilakukan untuk menganalisis mutu pendidikan taman kanak-kanak yang secara teoritis sangat dipengaruhi oleh kepemimpinan kepala sekolah terutama pada aspek motivasi berprestasi dan gaya kepemimpinan kepala sekolah. Dari temuan analisis deskriptif pada mutu pendidikan Taman kanak-kanak menunjukan bahwa perbaikan mutu terus menerus belum secara maksimal dilakukan. Sedangkan pada motivasi berpretasi menunjukkan bahwa kebutuhan akan kekuasaan kepala sekolah masih kurang kuat dan perlu di tingkatkan

Dari hasil uji hipotesis, menunjukan bahwa, jika bersama-sama antara motivasi berprestasi dan gaya kepemimpinan kepala sekolah memberikan kontribusi lebih tinggi dari pada pengaruh masing-masing variabel secara sendirisendiri. Dan pengaruh motivasi berprestasi lebih besar dari pada pengaruh gaya kepemimpinan kepala sekolah terhadap mutu pendidikan taman kanak-kanak.

\section{REKOMENDASI}

Perlu adanya roling atau pergantian kepala sekolah, selain itu kepala sekolah harus meningkatkan kualifikasi akademik dan kompetensi Penddk dan Tenaga Kependidikan. Serta membentuk sistem penjaminan mutu internal (SPMI) dan sistem penjaminan mutu eksternal (SPME) sehingga mempunyai peta mutu pendidikan dan dapat melakukan perbaikan mutu terus-menerus.
Rekomendasi untuk penelitian lain agar Penelitian selanjutnya diharapkan melakukan penelitian dengan metode kualitatif untuk lebih mendalam mengenai mutu pendidikan taman kanak-kanak dengan menambah kan variabel lain yang diduga dapat mempengaruhi mutu pendidikan taman kanak-kanak sehingga dapat memberikan kontribusi yang lebih luas terhadap penelitian

\section{DAFTAR PUSTAKA}

Alkahtani, A. H. et al. (2016) 'The Influence of Leadership Styles on Organizational Commitment: The Moderating Effect of Emotional Intelligence', Business and Management Studies, 2(1), pp. 23-34. doi: 10.11114/bms.v2i1.1091.

Amanchukwu, R. N., Stanley, G. J. and Ololube, N. P. (2015) 'A Review of Leadership Theories, Principles and Styles and Their Relevance to Educational Management', Management, 5(1), pp. 6-14. doi: 10.5923/j.mm.20150501.02.

Amofa, A. K., Okronipa, G. A. and Boateng, K. (2016) 'Leadership styles and organisational Productivity: A case study of Ghana
Cement Limited', European Journal of Business and Management, 8(2), pp. 131143. ISSN: 2222-2839.

Bipp, T. and Dam, K. Van (2014) 'Extending hierarchical achievement motivation models : The role of motivational needs for achievement goals and academic performance', Personality and Individual Differences. Elsevier Ltd, 64, pp. 157-162. doi: 10.1016/j.paid.2014.02.039.

Botha, R. J. N. (2013) 'Effective Leadership towards Quality Outcomes in South African Education', International Journal of Educational Sciences ISSN: 0975-1122, 
5(3), pp. 283-291. doi: 10.1080/09751122.2013.11890088.

Chan, C. W. (2014) 'The leadership styles of Hong Kong kindergarten principals in a context of managerial change', Educational Management Administration \& Leadership, 42(1), pp. 30-39. doi: $10.1177 / 1741143213499263$.

Dhaniarti, I., Wulandari, A. and Setiawan, I. (2017) 'Kajian Gender Leadership and Inequality Pada Perguruan Tinggi Di Indonesia', Jurnal Darussalam; Jurnal Pendidikan, Komunikasi dan Pemikiran Hukum Islam, VIII(2), pp. 20-32.

Ekada, A., Mirfani, A. M. and Sutarsih, C. (2016) 'Kontribusi kualitas kehidupan kerja, motivasi berprestasi kepala sekolah dan kinerja kepala sekolah', Jurnal Administrasi Pendidikan, XXIII(2), pp. 141-148.

Engkoswara and Komariah, A. (2012) Administrasi Pendidikan. Bandung: Alfabeta.

Falimu (2017) 'Etika Komunikasi Pegawai Terhadap Pelayanan Penerbitan Pajak Bumi dan Bangunan', Jurnal Komunikator, 9(1), pp. 9-16.

Flanagan, K. and Associates (2018) 'CONTINUOUS QUALITY IMPROVEMENT : A Guide for Licensed Child Care Centres Department of Education and Early Childhood Development', Nova Scotia, January.

Gaytán, S. P. (2014) 'Gender and Leadership : an Approach to the Differences between Women and Men in Management', Hyperion Economic Journal, 1(2), pp. 3-11.

Gözükara, İ., Hatipo, Z. and Öncel, Ö. (2017) 'The Impact of Perceived Leadership Style on Performance Appraisal Satisfaction and Organizational Diagnosis in terms of Turnover Intention', International Journal of Business and Management; Vol., 12(9), pp. 104-116. doi: 10.5539/ijbm.v12n9p104.

Hamstra, M. R. W. et al. (2014) 'Transformational and Transactional Leadership and Followers' Achievement Goals', Journal of Business and Psychology, 29(3), pp. 413425. doi: 10.1007/s10869-013-9322-9.

Hard, L., Press, F. and Gibson, M. (2013) “" Doing " Social Justice in Early Childhood:', Contemporary Issues In Early Childhood, 14(4), pp. 324-334.
Hariyanto, Muhdi and Abdullah, G. (2017) 'Pengaruh Motivasi Berprestasi Dan Supervisi Kepala Sekolah Terhadap Kompetensi Pedagogik Guru Madrasah Tsanawiyah (Mts) di kec. Kedung kab. Jepara', Jurnal Manajemen Pendidikan (JMP), pp. 236-250. doi: 10.24961/j.tek.ind.pert.2017.27.2.141.

Hartini, S. (2015) Pengaruh Kepemimpinan Visioner Kepala Sekolah dan Iklim Sekolah Terhadap Efektivitas Sekolah Pada Sekolah Dasar Negeri Di Wilayah Ciomas Kabupaten Bogor. Universitas Pendidikan Indonesia.

Heikka, J., Waniganayake, M. and Hujala, E. (2013) 'Contextualizing Distributed Leadership Within Early Childhood Education', Educational Management Administration \& Leadership, 41(1), pp. 3044. doi: 10.1177/1741143212462700.

Hirtz, P. D., Murray, S. L. and Riordan, C. A. (2007) 'The Effects of Leadership on Quality', Engineering Management Journal, 19(1), pp. 22-27. doi: 10.1080/10429247.2007.11431718.

Hoxha, L. and Hyseni-duraku, Z. (2017) 'The Relationship between Educational Leadership and Teachers ' Self-efficacy', The European Journal of Social and Behavioural Sciences (EJSBS), XX, pp. 2508-2519. http://dx.doi.org/10.15405/ejsbs.221.

Hoy, W. K. and G.Miskel, C. (2014) Administrasi Pendidikan: Teori, Riset dan Praktik. 1st edn. Yogyakarta: Pustaka Pelajar.

Jeremy Mitonga-Monga, Coetzee, M. and Cilliers, F. V. N. (2012) 'Perceived leadership style and employee participation in a manufacturing company in the democratic republic of Congo', African Journal of Business Management, 6(15), pp. 53895398. doi: 10.5897/AJBM11.2443.

Jha, S. (2010) 'Need for growth, achievement, power and affiliation: Determinants of psychological empowerment', Global Business Review, 11(3), pp. 379-393. doi: 10.1177/097215091001100305.

Kharis, A., Sudharto and Yuliejantiningsih, Y. (2016) 'Pengaruh Budaya Sekolah Dan Motivasi Berprestasi Terhadap Mutu Sekolah Dasar Negeri Di Uptd Pendidikan Kecamatan Kabupaten Brebes', Jurnal Manajemen Pendidikan (JMP), 5(1), pp. 
$105-120$.

doi:

http://dx.doi.org/10.26877/jmp.v5i1.1926.

Khoerudin, Hernawan, D. and Purnamasari, I. (2017) 'External Coordination Of Traffic And Road Transportation Agency About Implementation Of One Way Direction System', Jurnal Governansi, 3(2), pp. 6370. ISSN: 2442-3971.

Kroth, M. (2007) Manager As Motivator. Westport: Greenwood Publishing Group, Inc.

Leaton Gray, S. (2013) 'The "Big Society", Education and Power', Power and Education, 5(3), pp. 248-261. doi: 10.2304/power.2013.5.3.248.

Makura, A. H. (2012) 'Leadership Styles of Female Educational Leaders : In Search of a Gender Inclusive Leadership Theory', Journal of Social Sciences, 31(3), pp. 279287.

doi: 10.1080/09718923.2012.11893037.

Mangkunegara, A. P. (2013) Manajemen Sumber Daya Manusia Perusahaan. Kesebelas. Bandung: PT. Remaja Rosdakarya.

Maris, I. S., Komariah, A. and Bakar, A. (2016) 'Kepemimpinan Transformasional Kepala Sekolah, Kinerja Guru Dan Mutu Sekolah', Jurnal Administrasi Pendidikan, XXIII(2).

Michou, A. et al. (2016) 'Building on the Enriched Hierarchical Model of Achievement Motivation: Autonomous and Controlling Reasons Underlying Mastery Goals', Psychologica Belgica, 56(3, SI), pp. 269287. doi: $10.5334 / \mathrm{pb} .281$.

Muthanna, A. (2015) 'Quality education improvement: Yemen and the problem of the "brain drain", Policy Futures in Education, 13(1), pp. 141-148. doi: $10.1177 / 1478210314566734$.

Nanjundeswaras, T. S. and Swamy, D. R. (2014) 'Leadership Styles', Advances in Management, 7(2), pp. 57-63. doi: 10.1016/B978-1-84334-658-6.50003-6.

Neigel, A. R. et al. (2017) 'Individual differences in achievement motivation are related to vigilance performance', Proceedings of the Human Factors and Ergonomics Society, 2017-October, pp. 1298-1302. doi: $10.1177 / 1541931213601807$.

Nir, A. E. and Kafle, B. S. (2013) 'The effect of political stability on public education quality', International Journal of
Educational Management, 27(2), pp. 110126. doi: doi:10.1108/09513541311297487.

Norouzi, M. (2012) 'Relationship of Quality of Life and Achievement Motivation with Under Graduated Student's Anxiety', Journal of Depression \& Anxiety, 1(S1), pp. 1-4. doi: 10.4172/scientificreports.114.

Pavlovic, N. (2015) 'School Directors and Differences in Leadership Style Depending on Gender School', The Anthropologist, 21(1-2), pp. 254-261. doi: 10.1080/09720073.2015.11891814.

Peraturan Direktur Jenderal Pendidikan Anak Usia Dini Dan Pendidikan Masyarakat Kementerian Pendidikan Dan Kebudayaan Nomor 01 Tahun 2016 Tentang Petunjuk Teknis Pemetaan Mutu Program Dan/Atau Satuan Pendidikan Anak Usia Dini Dan Pendidikan Masyarakat.

Peraturan Menteri Pendidikan dan Kebudayaan Republik Indonesia Nomor 137 Tahun 2014 tentang Standar Nasional Pendidikan Anak Usia Dini.

Pieterse, A. N. et al. (2009) 'Transformational and transactional leadership and innovative behavior: The moderating role of psychological empowerment ANNE', Journal of Organizational Behavior, 31, pp. 609-623. doi: 10.1002/job.650.

Prabowo, B. S. (2012) Pelaksanaan Standar Pengelolaan Pendidikan di SMP Negeri 3 Godean. Universitas Negeri Yogyakarta.

Rincón, V., González, M. and Barrero, K. (2017) 'Women and leadership : Gender barriers to senior management positions', Intangible Capital, 13(2), pp. 319-386. doi: http://dx.doi.org/10.3926/ic.889.

Robbins, S. P. and Coulter, M. (2010) Manajemen. Kesepuluh. Edited by N. I. Sallama. Jakarta: Penerbit Erlangga.

Saepudin, J. (2017) 'Mutu Raudhatul Athfal Di Kota Jambi Dalam Perspektif Standar Pendidikan Anak Usia Dini', Jurnal Penelitian Keagamaan Dan Kemasyarakatan (Penamas, 30(2), pp. 163$182 . \quad$ doi: https://doi.org/10.31330/penamas.v30i2.12 6.

Sallis, E. (2012) Total Quality Management In Education. Yogyakarta: IRCisoD.

Sari, D. P. (2013) 'Kontribusi Gaya Kepemimpinan Kepala Sekolah Dan Motivasi Berprestasi Guru Terhadap Mutu 
Pendidikan Di Gugus Rama 2 Upt Disdikpora Kecamatan Kembang Kabupaten Jepara', JMP, 2(1), pp. 92-104.

Satori, D. (2016) Pengawasan dan Penjaminan Mutu Pendidikan. Bandung: Alfabeta.

Sonedi (2013) 'Kepemimpinan Visioner: Solusi Peningkatan Kualitas Persekolahan', Pedagogik Jurnal Pendidikan, 8(2), pp. 113.

Sujiono, Y. N. and Sujiono, B. (2010) Bermain Kreatif Berbasis Kecerdasan Jamak. 1st edn. Jakarta: PT Indeks.

Thoha, M. (2015) Kepemimpinan Dalam Manajemen. 1st edn. Jakarta: Rajawali Pers.

Undang - undang Republik Indonesia Nomor 20 tahun 2003 tentang Sistem Pendidikan Nasional.
Undang-undang Republik Indonesia Nomor 23 tahun 2014 tentang Pemerintah Daerah.

Veliu, L. et al. (2017) 'The influence of leadership Styles on Employee Performance', Vadyba Journal of Management, 31(2), pp. 59-69.

Von Krogh, G., Nonaka, I. and Rechsteiner, L. (2012) 'Leadership in organizational knowledge creation: A review and framework', Journal of Management Studies, 49(1), pp. 240-277. doi: 10.1111/j.1467-6486.2010.00978.x.

Wau, Y. (2014) 'Kemampuan Pribadi dan Peningkatan Motivasi Berprestasi Kepala Sekolah', Jurnal Teknologi Pendidikan, pp. $57-76$.

Yus, A. (2015) Penilaian Perkembangan Belajar Anak Taman Kanak-kanak. Pertama, c. Jakarta: Prenadamedia Group. 